\title{
Comparison of normal and tumorigenic endothelial cells: differences in thrombospondin production and responses to transforming growth factor-beta
}

\section{Citation}

RayChaudhury, Amlan, William A. Frazier, Patricia A. D'Amore. 1994. Comparison of normal and tumorigenic endothelial cells: differences in thrombospondin production and responses to transforming growth factor-beta. Journal of Cell Science 107(Pt 1):39-46

\section{Permanent link}

http://nrs.harvard.edu/urn-3:HUL.InstRepos:36304245

\section{Terms of Use}

This article was downloaded from Harvard University's DASH repository, and is made available under the terms and conditions applicable to Other Posted Material, as set forth at http:// nrs.harvard.edu/urn-3:HUL.InstRepos:dash.current.terms-of-use\#LAA

\section{Share Your Story}

The Harvard community has made this article openly available. Please share how this access benefits you. Submit a story.

Accessibility 


\title{
Comparison of normal and tumorigenic endothelial cells: differences in
}

\section{thrombospondin production and responses to transforming growth factor-beta}

\author{
Amlan RayChaudhury ${ }^{1,2, *}$, William A. Frazier ${ }^{3}$ and Patricia A. D'Amore ${ }^{1,2,4, \dagger}$ \\ ${ }^{1}$ Laboratory for Surgical Research, Children's Hospital, Boston, MA 02115, USA \\ 2Department of Surgery, Harvard Medical School, Boston, MA 02115, USA \\ 3Department of Biochemistry and Molecular Biophysics, Washington University School of Medicine, St. Louis, MO 63110, USA \\ 4Department of Pathology, Harvard Medical School, Boston, MA 02115, USA \\ *Present address: Rush University, St. Luke's Medical Center, Department of Pharmacology, Chicago, IL 60612, USA \\ †Author for correspondence
}

\section{SUMMARY}

Cultured endothelial cells constitutively synthesize significant levels of thrombospondin, an extracellular matrixassociated protein with reported anti-angiogenic properties. However, two murine endothelial cell lines, bEND.3 and Py-4-1, which have been immortalized with polyoma $T$ oncogenes and which generate vascular malformations in vivo, produce little or no thrombospondin though bEND.3 (but not Py-4-1) growth is inhibited by the addition of exogenous thrombospondin. In addition, Py-4-1 cells are not growth-inhibited by transforming growth factor-beta, a potent endothelial inhibitor. These results indicate that these two cell lines may be useful tools in understanding the role and mechanism of action of thrombospondin and transforming growth factor-beta in endothelial cell biology. A role for thrombospondin in vascular development is further suggested by the observation of significant differences in the levels of thrombospondin mRNA and protein between capillary and aortic endothelial cells. Transform- ing growth factor-beta-1 treatment of normal endothelial cells increases steady-state levels of thrombospondin mRNA and protein and results in extensive deposition of thrombospondin into the extracellular matrix. In contrast, transforming growth factor-beta-1 has little effect on thrombospondin levels in the tumorigenic endothelial cell lines. In view of our earlier finding that contact between endothelial cells and mural cells generates activated transforming growth factor-beta-1, and the fact that thrombospondin is present in a fibrillar network around vascular structures in vitro, we speculate that modulation of thrombospondin production and distribution by transforming growth factor-beta may be a physiological process to enjoin stabilization of vessels and cessation of vessel growth.

Key words: angiogenesis, endothelial cell, extracellular matrix, TGF$\beta$, thrombospondin, vascular malformation

\section{INTRODUCTION}

In contrast to the relatively quiescent endothelium of normal adult blood vessels (Engerman et al., 1967; Hobson and Denekamp, 1984), cultured endothelial cells (EC) have a high labeling index (Folkman et al., 1979). The growth of cultured EC is modulated by various agents, such as basic fibroblast growth factor (bFGF), which stimulates their proliferation (Vlodavsky et al., 1979; Baird et al., 1985a,b) and transforming growth factor type-beta (TGF- $\beta$ ), a potent growth inhibitor (Baird and Durkin, 1986; Frater-Schroder et al., 1986; Heimark et al., 1986). Under appropriate circumstances certain factors such as bFGF (Montesano et al., 1986) and phorbol esters (Montesano and Orci, 1985) induce EC in vitro to form tubelike structures similar to microvessel networks, whereas TGF$\beta$ inhibits the phorbol ester-induced in vitro 'angiogenesis' (Muller et al., 1987). Thus, cultured EC constitute a system in which regulation of EC growth, migration and differentiation parallels the in vivo events of angiogenesis and in which the roles of different growth effectors may be studied.
An approach that may further elucidate mechanisms involved in the regulation of EC behavior is a comparison of normal EC to cell lines that are derived from normal EC but that have altered growth properties. One such EC line, bEND.3, was generated by infecting cultured mouse brain capillary EC with a retrovirus carrying the polyoma middle T oncogene (Montesano et al., 1990). bEND.3 cells, unlike cultured normal EC, have an indefinite life span, an accelerated doubling time and are not significantly contact-inhibited. In addition, they have increased cell-associated proteolytic activity that appears to account for their irregular morphogenetic behavior in vitro, including formation of cyst-like cavities rather than tube-like structures in fibrin gels (Montesano et al., 1990). The endothelial character of bEND. 3 cells, however, is demonstrated by the fact that they synthesize von Willebrand factor and have receptors for acetylated low density lipoprotein. When injected into embryonic and newborn mice, bEND.3 cells induce rapidly growing tumors that are lethal in embryonic mice but spontaneously regress in newborn and young mice (W. Risau, 
personal communication). These tumors resemble vascular malformations, consisting of a central blood-filled cavern surrounded by few layers of smooth muscle cells. These observations suggest that in bEND. 3 cells one or more of the processes governing normal endothelial growth, migration and differentiation have been altered or eliminated in this EC line.

Another EC line, Py-4-1, was isolated from vascular tumors arising in transgenic mice carrying the entire polyoma early genetic region (Dubois et al., 1991). Py-4-1 cells express all three polyoma T-antigens and, like bEND.3 cells, grow at a faster rate than normal capillary EC. When injected into mice, Py-4-1 cells also give rise to tumors that resemble vascular malformations. The tumors form stable structures that can exist for several months, although they are invariably lethal. Thus, Py-4-1 cells and bEND.3 cells may share certain common features that differ from normal EC and that may contribute to their tumorigenic phenotype.

To gain insight into mechanisms that regulate EC growth and differentiation, we have begun to characterize differences between these tumorigenic cells and normal EC. We have focused our attention on two molecules, TGF- $\beta 1$ and thrombospondin-1 (TSP-1), which are known to regulate EC behavior. Previous work from our laboratory (AntonelliOrlidge et al., 1989) and others (Sato and Rifkin, 1989) has established that when EC and mural cells (smooth muscle cells and pericytes) are grown in coculture, physical contact between the two cell types results in the activation of TGF$\beta$ which inhibits EC growth. This observation may be significant in view of the extensive contacts that EC and mural cells make throughout the vasculature (Rhodin, 1968). The possibility that TGF- $\beta$ is activated locally within the vasculature, together with the reported effects of TGF- $\beta$ on angiogenesis (Muller et al., 1987; Merwin et al., 1990), strongly suggests that it plays a role in vascular development and maintenance.

TSP-1, a matrix-associated trimeric glycoprotein, has gained interest as an EC-modulating agent; a fragment called gp-140, whose expression in some cells is regulated by a tumor suppressor gene, has been found to be anti-angiogenic in vivo (Good et al., 1990). In addition, expression of TSP-1 gene in cultured fibroblasts (Penttinen et al., 1988) and smooth muscle cells (Majack et al., 1990; Kobayashi and Yamamoto, 1991) is regulated by TGF- $\beta 1$, raising the possibility of the coordinate involvement of TGF- $\beta$ and TSP in the regulation of angiogenesis. Soluble TSP-1 has also been reported to be an inhibitor of EC growth (Bagavandoss and Wilks, 1990; Taraboletti et al., 1990).

In this paper we describe the results of our studies comparing normal EC and bEND.3 cells with regards to the action of TGF- $\beta 1$ and their production of TSP- 1 . Our results indicate a selective loss or reduction of TSP-1 mRNA and protein in the tumorigenic cells and a TGF- $\beta$-induced increase in and redistribution of TSP-1 in normal but not tumorigenic cells. However, tumorigenic and normal cells are equally inhibited by the addition of exogenous TSP. These findings, together with observations of differences in TSP-1 expression between large and microvessel EC, support the concept that TSP may contribute to the development and stabilization of vascular structures.

\section{MATERIALS AND METHODS}

\section{Cell culture}

Bovine capillary EC, supplied by C. Butterfield and Dr J. Folkman (The Children's Hospital, Boston, MA), were grown on gelatinized surfaces (1.5\% in PBS) in Dulbecco's modified Eagle's medium (DMEM; JRH Biosciences, Lenexa, KS) containing 10\% calf serum (CS) and supplemented with $2 \mathrm{mM}$ glutamine, 100 units $/ \mathrm{ml}$ each of penicillin and streptomycin (Irvine Scientific, Santa Ana, CA) and 2$3 \mathrm{ng} / \mathrm{ml}$ human recombinant bFGF (provided by Takeda Chemical Industries, Ltd, Osaka, Japan). Rat brain EC, provided by Dr Susan Doctrow (Alkermes Inc, Cambridge, MA), were grown on gelatinized surfaces in 10\% FCS-containing DMEM/F12 (1:1) supplemented with glutamine, penicillin and streptomycin as above, and $100 \mu \mathrm{g} / \mathrm{ml}$ heparin and 12.5-25 $\mu \mathrm{g} / \mathrm{ml}$ endothelial cell growth supplement (Sigma, St. Louis, MO). Rat aortic EC, provided by Dr John Doukas (University of Massachusetts School of Medicine, Worcester, MA), were grown on fibronectin- $\left(2 \mu \mathrm{g} / \mathrm{cm}^{2}\right)$ and gelatin (1.5\% in PBS)coated surfaces in the same medium as the rat brain EC. EC from bovine aortae were isolated by gently scraping the intimal surface with a scalpel blade and were grown in 10\% CS-containing DMEM. bEND. 3 cells were supplied by Dr Werner Risau (Max Planck Institüt, Martinsried, Germany) and were grown in DMEM containing $10 \%$ CS. Py-4-1 cells were provided by Dr Vicki Bautch (University of North Carolina, Chapel Hill, NC) and were grown in DMEM containing $10 \% \mathrm{CS}$. All cells were grown in $10 \% \mathrm{CO}_{2}$ at $37^{\circ} \mathrm{C}$. Human recombinant TGF- $\beta 1$ was provided by Oncogen (Seattle, WA). At confluence cells were passaged with trypsin-EDTA $(0.05 \%$ trypsin/0.53 mM Na4EDTA) for 1-5 minutes. To grow cells in TGF$\beta$, media were aspirated, cells were washed with PBS and refed with fresh media containing serum and TGF- $\beta 1$ (at the indicated concentrations) but no other growth factors.

\section{Northern analysis}

Total cellular RNA was isolated by lysis of cells with guanidinium isothiocyanate followed by ultracentrifugation on $\mathrm{CsCl}$ (Chirgwin et al., 1979). Total cellular RNA ( $15 \mu \mathrm{g})$ from each sample was resolved on formaldehyde-agarose gels and transferred to nitrocellulose paper (Thomas, 1980). Blots were hybridized to ${ }^{32} \mathrm{P}$-labeled cDNA probes $\left(1-5 \times 10^{6} \mathrm{dpm} / \mathrm{ml}\right)$ in a hybridization solution consisting of $50 \%$ deionized formamide, $750 \mathrm{mM} \mathrm{NaCl}, 75 \mathrm{mM}$ sodium citrate, $20 \mathrm{mM}$ HEPES, pH 7.4, 1 mM EDTA, $10 \mu \mathrm{g} / \mathrm{ml}$ tRNA, $0.01 \%$ BSA, $0.02 \%$ Ficoll-400, $0.02 \%$ polyvinylpyrrolidone-360, $10 \mu \mathrm{g} / \mathrm{ml}$ sonicated salmon sperm DNA (Sigma) at $42^{\circ} \mathrm{C}$. After hybridization, blots were washed with $0.1 \%$ SDS, $0.1 \times \mathrm{SSC}$ at $50^{\circ} \mathrm{C}$ and exposed to an X-ray film overnight (or longer if necessary).

\section{Probes}

All probes used for northern blots were labeled with ${ }^{32} \mathrm{P}$. TSP-1 probe was made against a $4.4 \mathrm{~kb} \mathrm{BamH1-HindIII} \mathrm{fragment} \mathrm{digested} \mathrm{from}$ the full-length human cDNA (Hennessy et al., 1989). A probe for secreted protein acidic and rich in cysteine (SPARC) was made against a 550 bp BamHI-EcoRI mouse cDNA fragment, supplied by Dr Helene Sage (University of Washington, Seattle, WA). Glyceraldehyde 3-phosphate dehydrogenase (GAPDH) probe was made against a $1.3 \mathrm{~kb}$ Pst I fragment digested from rat GAPDH cDNA (Fort et al., 1985).

\section{Immunofluorescence}

Cells were grown on Lab-Tek chamber slides for 3 days, fixed in $4 \%$ paraformaldehyde in PBS for 15 minutes at room temperature, permeabilized with $0.2 \%$ Triton X-100 and stained with $15 \mu \mathrm{g} / \mathrm{ml}$ of antihuman TSP-1 monoclonal antibody (Prater et al., 1991) for 30-60 minutes at $37^{\circ} \mathrm{C}$. Cells were then washed three times with PBS (10 minutes each) and incubated with a 1:75 dilution of rhodaminelabeled goat anti-mouse IgG (Boehringer Mannheim, Indianapolis, 
IN) as above. Slides were mounted with antifade mounting medium (90\% glycerol, $0.1 \%$ phenylenediamine, $\mathrm{pH} 9$ in PBS), coverslipped and viewed with a Zeiss microscope.

\section{Cell proliferation assays}

Cells were plated at a density of 5000 cells $/ \mathrm{cm}^{2}$ in $24-$ or 48 -well dishes in DMEM containing serum. The next day unattached cells were removed and the number of cells plated $\left(\mathrm{T}_{0}\right)$ was determined in one well. The cells were then refed with the same medium and the factor being studied (3-4 wells per data point). Rat brain EC were plated at higher densities because they did not plate or grow well at low densities in the absence of growth factors. Assays were conducted over a 3-day period and cells were counted electronically using a Coulter counter. Statistical analyses were performed using the InStat ${ }^{\circledR}$ program (Graph Pad, San Diego, CA).

\section{RESULTS}

\section{TGF- $\beta 1$ inhibits proliferation of rat brain, bovine capillary and bEND.3 EC but not of Py-4-1 cells}

Because of the potentially important role of TGF- $\beta$ in EC growth control, we compared the response of normal and tumorigenic EC to TGF- $\beta 1$. Our earlier studies had shown that $0.25-0.5 \mathrm{ng} / \mathrm{ml}$ TGF- $\beta 1$ effected maximal inhibition of bovine capillary and aortic EC growth (D'Amore and Smith, 1993). We used a concentration of $1 \mathrm{ng} / \mathrm{ml}$ (two- to four-fold higher than the maximum inhibitory concentration) for all our studies. TGF- $\beta 1$ at $1 \mathrm{ng} / \mathrm{ml}$ significantly inhibited the growth of rat brain EC, bovine capillary EC, and bEND.3 cells, but not Py4-1 cells (Fig. 1). Further studies revealed that the proliferation of Py-4-1 cells was not inhibited by concentrations of TGF- $\beta 1$ up to $10 \mathrm{ng} / \mathrm{ml}$ or by $10 \mathrm{ng} / \mathrm{ml}$ TGF- $\beta 2$ (data not shown). We have not extensively studied TGF- $\beta 2$ because its inhibitory effect on EC is much weaker than that of TGF- $\beta 1$
(Jennings et al., 1988). Py-4-1 cells are one of the few examples of EC that retain endothelial characteristics, but are not inhibited by TGF- $\beta$.

\section{Steady-state level of TSP mRNA is very low in two tumorigenic EC lines}

Both TGF- $\beta 1$ and TSP- 1 have been implicated in the control of angiogenesis, and TGF- $\beta 1$ has been shown to drastically affect the production of TSP in several cell types (Penttinen et al., 1988; Majack et al., 1990). Thus, we compared production of TSP-1 in the tumorigenic EC lines to production by normal EC and assessed the effect of TGF- $\beta 1$ on TSP-1 production. Total RNA was isolated from rat brain capillary EC, bEND.3 cells, and Py-4-1 cells grown at their log phase for 3 hours in the absence and presence of TGF- $\beta 1(1 \mathrm{ng} / \mathrm{ml})$. Northern analysis of RNA from these cells with a TSP-1 cDNA probe revealed that normal EC produce substantial amounts of the 6 kb TSP-1 transcript (Fig. 2, lane 1). TSP-1 mRNA was undetectable in bEND. 3 cells and Py-4-1 cells showed very low levels (Fig. 2, lanes 3 and 5, respectively). TGF- $\beta 1$ increased the steady-state level of TSP- 1 mRNA in the normal cells about two-fold (Fig. 2, lane 2), whereas TGF- $\beta 1$ treatment of bEND. 3 cells (which prior to TGF- $\beta$ had no steady-state TSP1 mRNA) showed a low level of TSP-1 mRNA (Fig. 2, lane 4) and TGF- $\beta 1$-treated Py-4-1 cells showed a slight increase in steady-state levels of TSP-1 mRNA (Fig. 2, lane 6).

A number of functions ascribed to TSP are shared by SPARC, a glycoprotein secreted by cultured EC and vascular smooth muscle cells (Sage and Bornstein, 1991). SPARC has no structural homology to TSP-1, but like TSP-1, is an 'antiadhesive' molecule and is reported to inhibit EC growth (Funk and Sage, 1991). These similarities between SPARC and TSP led us to investigate whether the expression of SPARC is also altered in bEND. 3 and Py-4-1 cells. Northern analysis of RNA
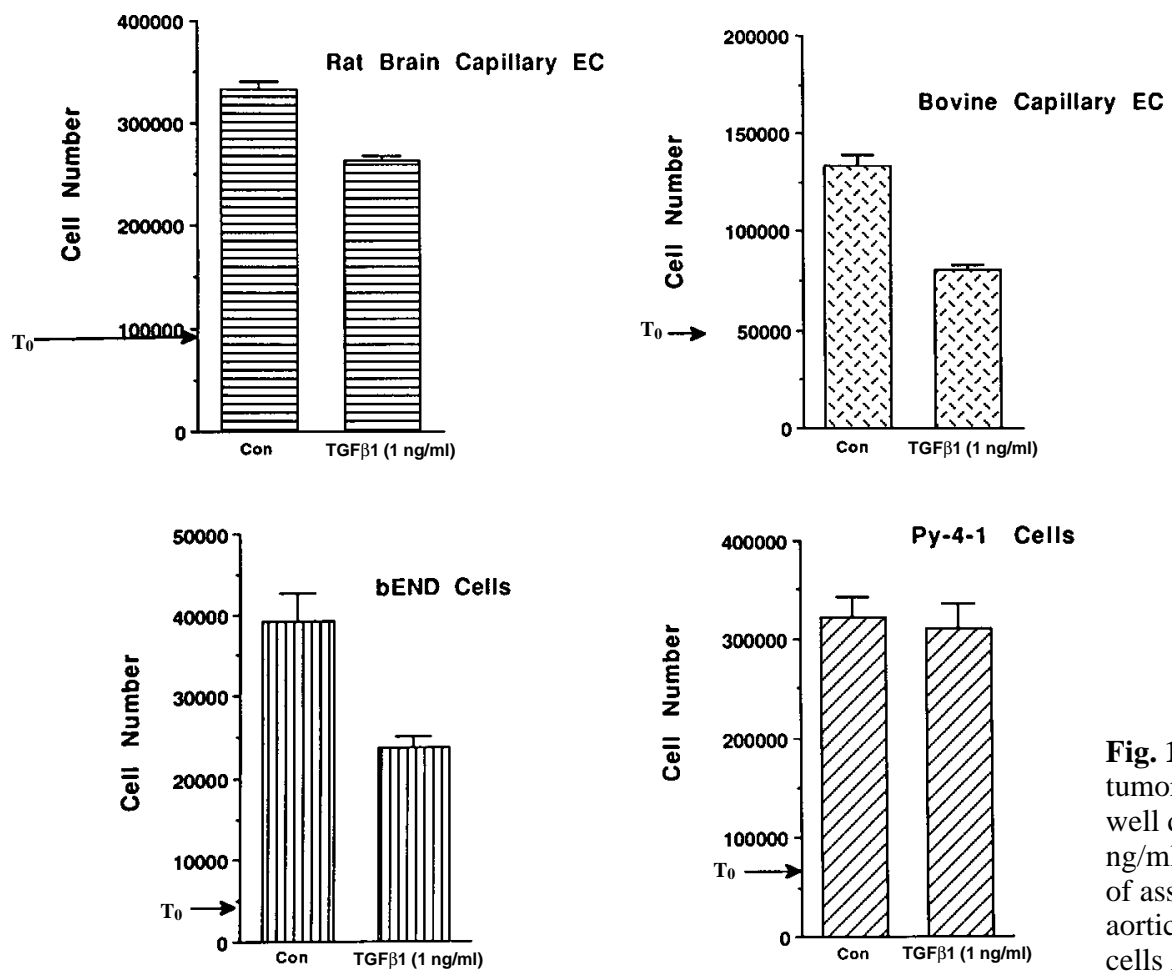

Fig. 1. Effect of TGF- $\beta$ on the growth of normal and tumorigenic EC. EC were grown in $2 \mathrm{~cm}^{2}$ wells of 24well dishes and assayed for the effect of TGF- $\beta$ ( 1 $\mathrm{ng} / \mathrm{ml}$ ) on growth over 3 days. $\mathrm{T}_{0}=$ cell number at start of assay; bars represent \pm s.d.. For rat cells, bovine aortic cells and bEND. 3 cells $P \leq 0.0001$; for Py- $4-1$ cells $P=0.4013$. 


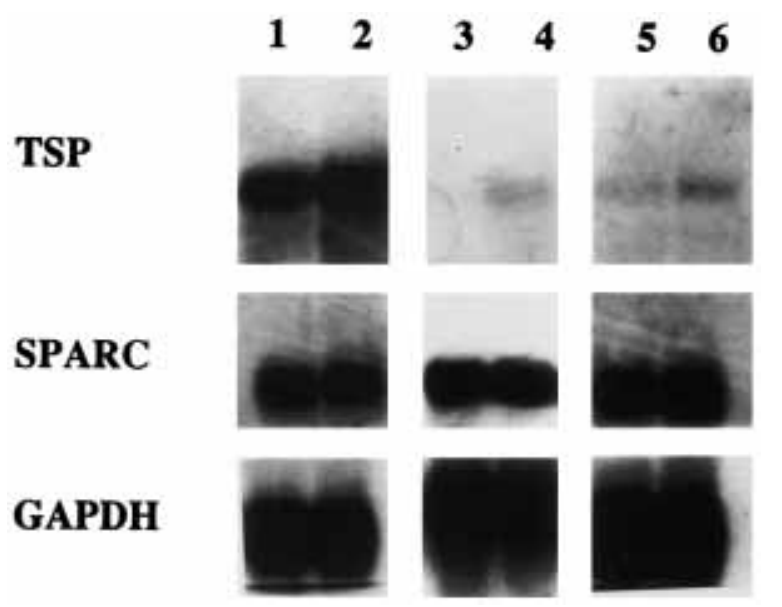

Fig. 2. Northern analysis of steady state levels of TSP and SPARC mRNA in normal and tumorigenic EC grown in the presence and absence of TGF- $\beta 1$. Total cellular RNAs are from: lanes 1 and 2, rat brain EC; 3 and 4, bEND. 3 cells; 5 and 6, Py-4-1 cells. Lanes 1, 3 and 5 are from untreated cells and lanes 2, 4 and 6 from cells treated with TGF- $\beta 1(1 \mathrm{ng} / \mathrm{ml})$ for 3 hours. mRNA sizes: TSP-1, $6 \mathrm{~kb}$; SPARC, $2.3 \mathrm{~kb}$; GAPDH, $1.5 \mathrm{~kb}$.

isolated from bEND.3 cells, Py-4-1 cells and rat brain EC with a SPARC cDNA probe showed no significant difference in steady-state levels of the $2.3 \mathrm{~kb}$ SPARC mRNA between normal EC and the EC lines (Fig. 2). In addition, TGF- $\beta 1$ did not significantly affect SPARC mRNA levels in any of the cells.

\section{TGF- $\beta 1$ increases and redistributes TSP-1 protein in normal EC}

To determine whether the TGF- $\beta 1$-induced increase in steadystate TSP-1 mRNA was associated with changes in synthesis of TSP protein, indirect immunofluorescence was performed on rat brain EC, bEND. 3 cells and Py-4-1 cells grown for 3 days with and without TGF- $\beta 1$. As shown in Fig. 3a, more than half of the untreated rat brain EC stained positively for TSP1 , with some cells staining very intensely. The variability in the staining among the cells is probably due to differences in cell cycle, since production of TSP-1 has been shown to be cell cycle-dependent in smooth muscle cells and these cells are not growing synchronously (Majack et al., 1990). TSP-1 labeling in TGF- $\beta 1$-treated rat brain EC was observed in almost every cell and the level of staining was more intense in the TGF- $\beta 1$ treated cells than in untreated cells (Fig. 3b). Moreover, more TSP-1 was localized in the extracellular matrix of TGF- $\beta 1$ treated cells than the untreated cells. In contrast, in the absence of TGF- $\beta$ virtually none of the bEND.3 (Fig. 3c) or Py-4-1 (Fig. 3e) cells stained positively for TSP-1. TGF- $\beta$-treated bEND.3 cells, showed a low level TSP labeling in a small number of cells (Fig. 3d); TSP protein was undetectable in TGF- $\beta$-treated Py-4-1 cells (Fig. 3f). Thus, whereas normal EC have substantial TSP mRNA and protein, which is increased by treatment with TGF- $\beta$, tumorigenic EC have little to no TSP and their TSP levels are not significantly influenced by TGF- $\beta$.

\section{Levels of TSP-1 mRNA and protein differ between large and small vessel EC}

The fact that the tumorigenic EC lines have no TSP-1 and form cavernous vascular malformations in vivo led us to postulate that TSP-1 may be involved in the determination of vessel diameter. We, therefore, compared TSP-1 levels in EC cultured from large vessels and from microvessels. Cultured rat aortic EC grown in the presence and absence of TGF- $\beta 1$ were stained for TSP-1 protein. Untreated rat aortic EC had very low levels of cell-associated TSP (Fig. 4a) compared to rat brain capillary EC (Fig. 4c). However, after exposure to TGF- $\beta 1$ for 3 days, there was a striking change in TSP-1 production and distribution; all cells treated with TGF- $\beta 1$ stained strongly for TSP-1, and there was abundant TSP-1 in the extracellular matrix (Fig.4b).

To rule out the possibility that the difference in TSP levels between the aortic and capillary TSP-1 was species-specific, steady-state levels of TSP-1 mRNA and TSP-1 protein were examined in cultured bovine capillary EC and aortic EC. Capillary EC had significantly higher levels of TSP-1 mRNA than aortic EC (Fig. 5a). In addition, nearly all of the capillary EC stained strongly for TSP-1 (Fig. 5b), whereas aortic EC stained much more weakly, with some cells barely labeled (Fig. 5c). As was true for rat EC, TGF- $\beta 1$ treatment of both bovine capillary and aortic EC led to a substantial increase in steady-state TSP-1 mRNA, and higher cell- and extracellular matrix-associated TSP-1 protein (data not shown). These experiments were carried out with cells at different densities and passage numbers, yielding essentially the same results. Thus, comparison of TSP-1 levels in capillary and aortic cells from two species suggests that capillary EC reproducibly synthesize more TSP-1 than aortic cells.

\section{Normal and tumorigenic EC are both inhibited by exogenous TSP}

In light of the reported ability of TSP to inhibit both the proliferation and migration of EC and the absence of TSP production by tumorigenic EC, we were interested in comparing the effects of TSP on the growth of normal capillary EC and bEND cells. Addition of TSP to rapidly growing cells led to a dose-dependent decrease in their proliferation (Fig. 6). Maximal growth inhibition of about $50 \%$ for both the normal and tumorigenic EC was observed at $10 \mathrm{ug} / \mathrm{ml} \mathrm{TSP}$.

\section{DISCUSSION}

Motivated by the demonstrated roles for TSP- 1 and TGF- $\beta 1$ in the regulation of EC growth and function, we compared TSP1 production and responses to TGF- $\beta 1$ in normal EC and two murine EC lines and found significant differences. Compared to normal EC, these two EC lines produce little or no TSP. Upon TGF- $\beta$ treatment, normal EC revealed increased levels of TSP mRNA and protein. The bEND. 3 cells, which prior to TGF- $\beta$ treatment have no TSP mRNA or protein, respond to TGF- $\beta$ by expressing a low level of TSP mRNA with scattered cells staining for TSP protein. Py-4-1 cells have a low level of TSP mRNA, which is increased following exposure to TGF$\beta$, but immunostaining reveals no detectable TSP protein, suggesting that a post-transcriptional mechanism is responsible for the lack of protein. The specificity of the absence of TSP-1 is highlighted by the observation that the steady-state levels of SPARC, a protein that shares many features with TSP, do not differ between the normal and tumorigenic EC. Our observa- 

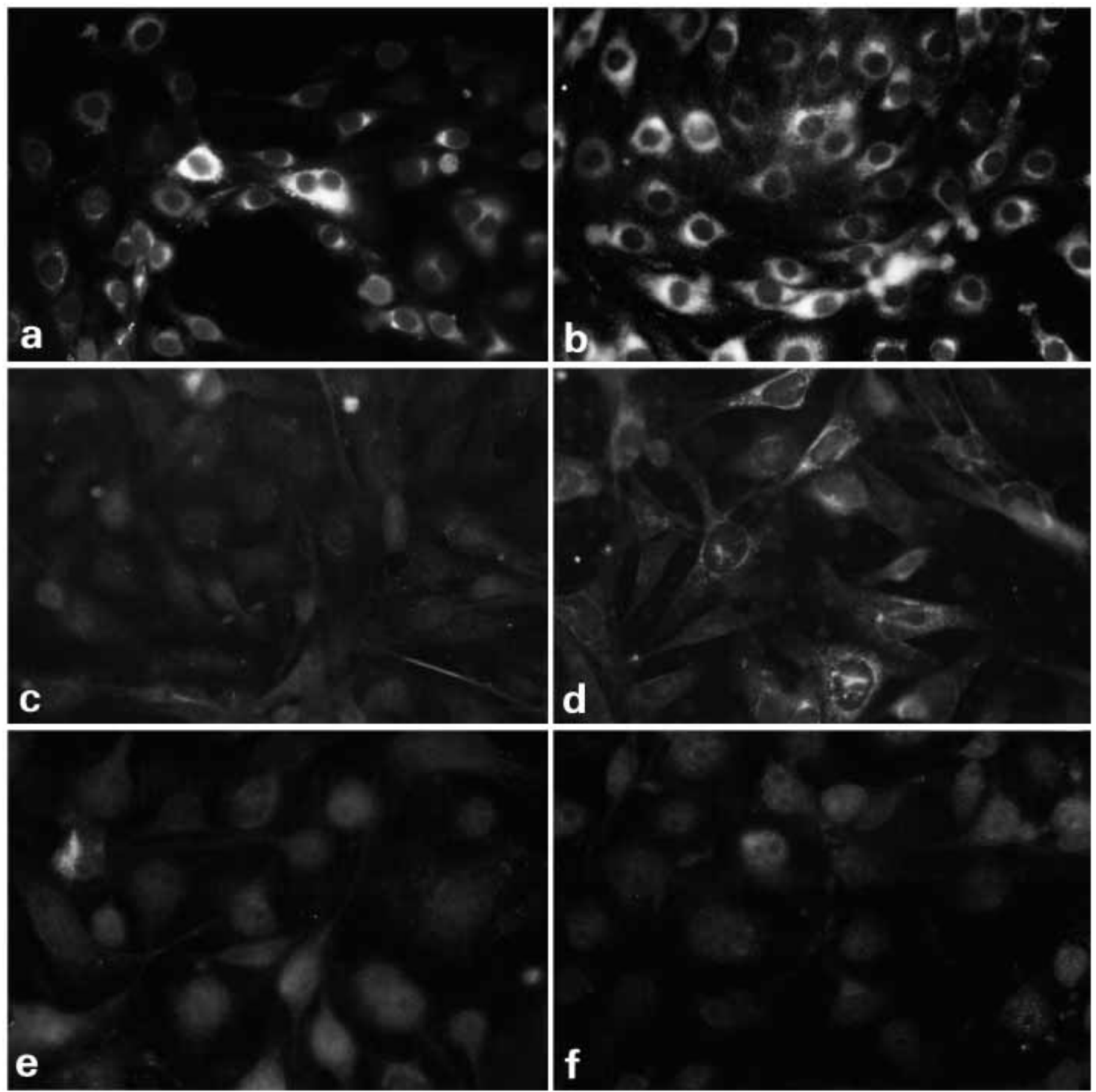

Fig. 3. Immunocytochemical localization of TSP in normal EC and tumorigenic EC. Rat brain capillary EC (a,b), bEND.3 cells (c,d) and Py-41 cells (e,f) were grown on Lab-Tek 4-chamber slides as described in Materials and Methods, immunostained with an anti-TSP monoclonal antibody and visualized at $\times 32$ magnification. Untreated cells (a,c,e); TGF- $\beta$-treated cells $(1 \mathrm{ng} / \mathrm{ml}$ for 3 days $)(b, d, f)$.

tion of significant levels of SPARC mRNA in bEND.3 cells is consistent with a recent report that these cells synthesize and secrete functional SPARC protein (Sage, 1992). A significant difference between these two cell lines is that the bEND.3 cells, but not Py-4- 1 cells, are inhibited by TGF- $\beta 1$, suggesting that resistance to the growth-inhibitory effect of TGF- $\beta 1$ may not play a role in the development of vascular malformations. Other differences have been reported between these immortalized cells and normal EC; Montesano et al. (1990) demonstrated that bEND.3 and other polyoma middle Texpressing endothelioma cells have increased cell-associated proteolytic activity, which accounts for some of their abnormal morphogenetic characteristics in vitro.

Though our observations do not demonstrate a causal link between the absence of TSP and the tumorgenicity of these EC lines, the known properties of TSP do support a role for TSP 

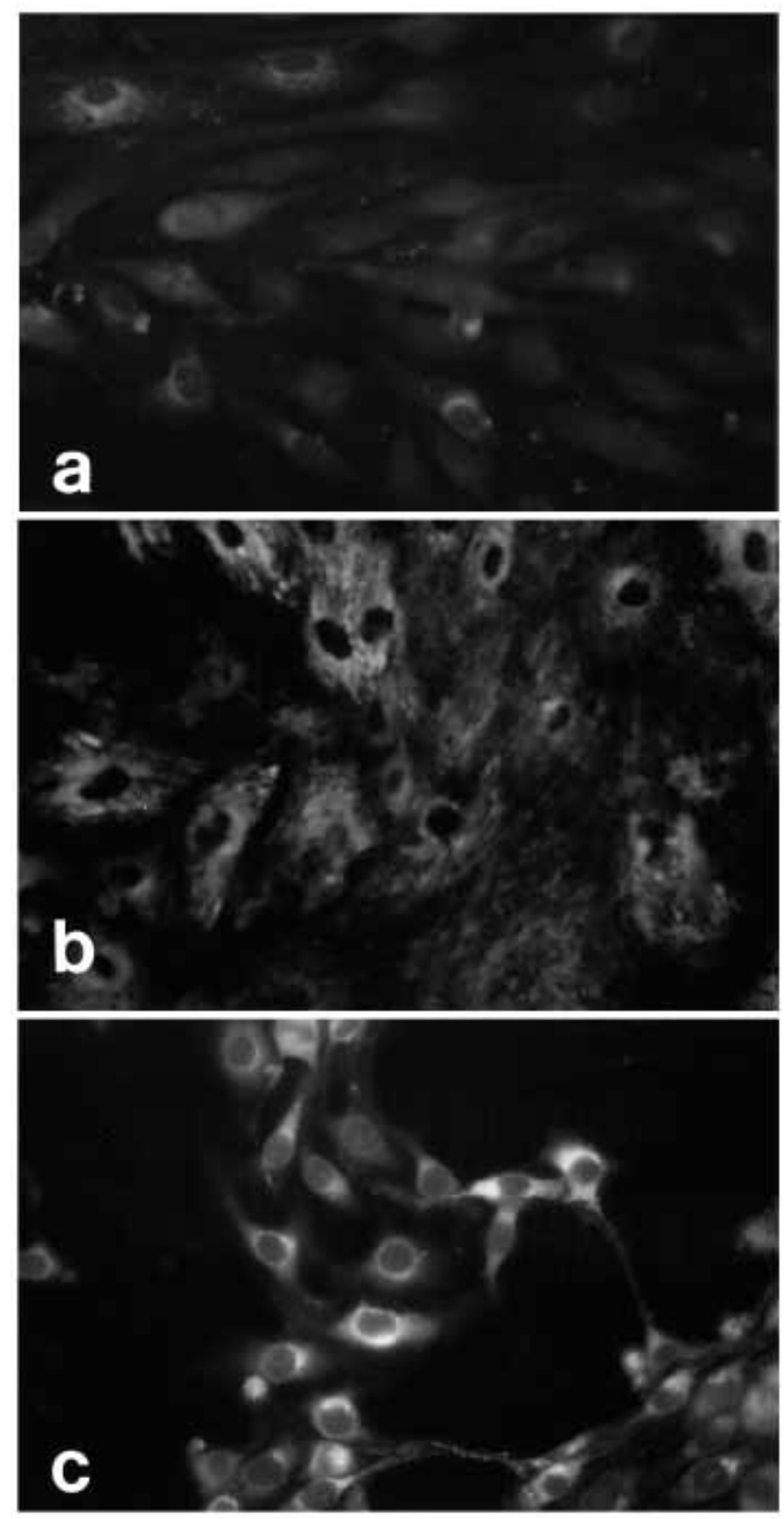

Fig. 4. Effect of TGF- $\beta$ on TSP production by rat aortic EC. Rat aortic EC were grown on Lab-Tek chamber slides, stained for TSP with anti-TSP monoclonal antibody and visualized at $\times 32$ magnification. Untreated cells (a); TGF- $\beta$-treated cells ( $1 \mathrm{ng} / \mathrm{ml}$ for 3 days) (b); untreated rat capillary cells $(c)(\times 50)$.

in the control of EC function. A number of reports have indicated TSP to be a regulator of vessel formation. Good et al. (1990) identified gp-140, an inhibitor of angiogenesis and capillary EC migration regulated by a tumor-suppressor gene, to be a fragment of TSP. More recently, this inhibitory activity has been localized to a 19 amino acid region of the central 70 $\mathrm{kDa}$ stalk of the molecule (Tolsma et al., 1993). In addition, this fragment inhibits both bFGF-stimulated migration and
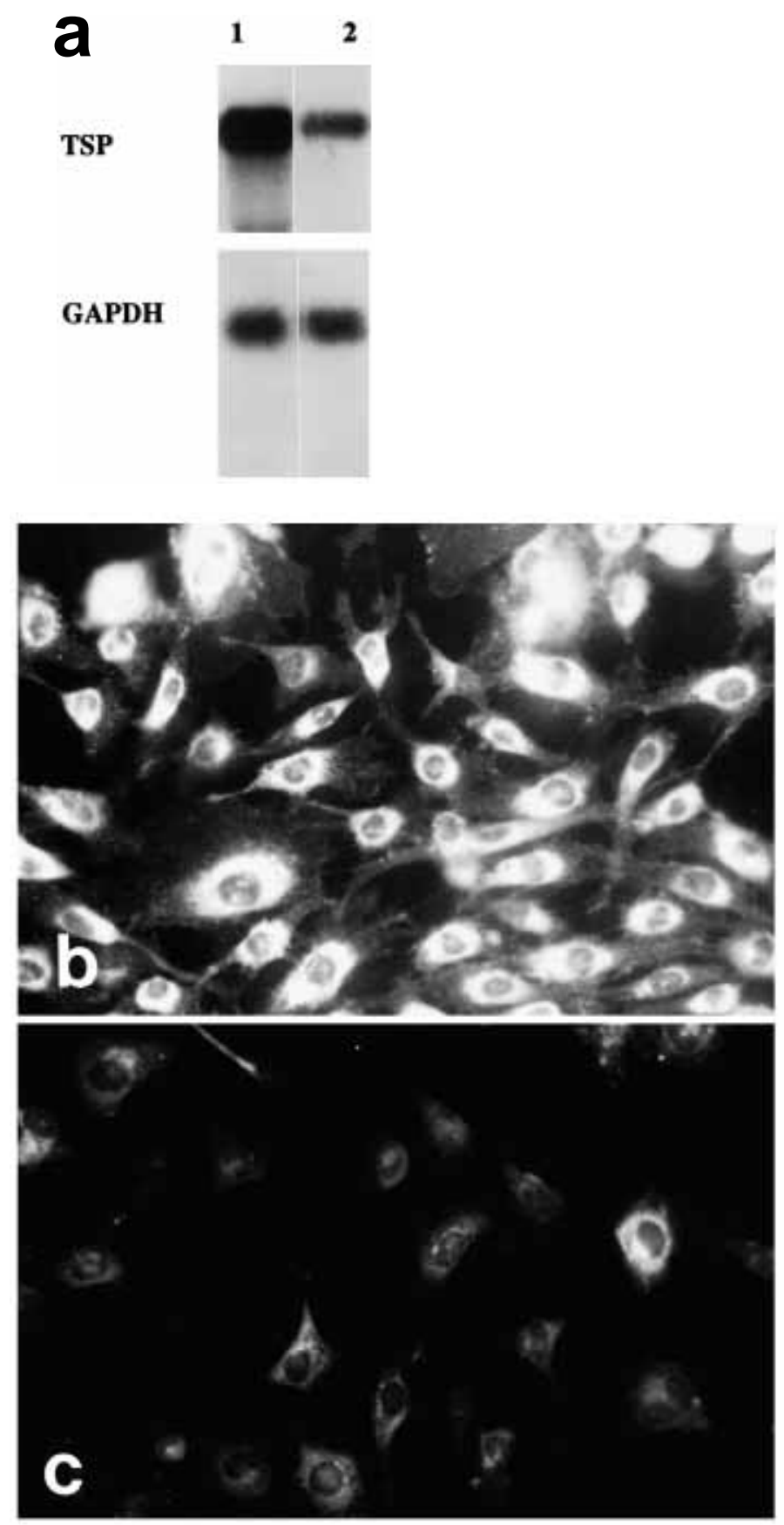

Fig. 5. Production of TSP by bovine capillary and aortic EC. TSP levels in rapidly growing bovine capillary and aortic EC were determined by northern hybridization and immunofluorescence. (a) Northern analysis of TSP mRNA: lane 1, bovine capillary EC; lane 2, bovine aortic EC. GAPDH mRNA levels used as internal control. Localization of TSP protein in bovine capillary EC (b) and bovine aortic EC (c).

DNA synthesis by cultured EC. Iruela-Arispe et al. (1991a) found an inverse correlation between TSP protein mRNA production and the extent of cord formation in cord-containing EC cultures. In contrast, SPARC mRNA levels, which are not affected in the established EC lines we studied, are actually upregulated in cord-containing EC cultures (Iruela-Arispe et 

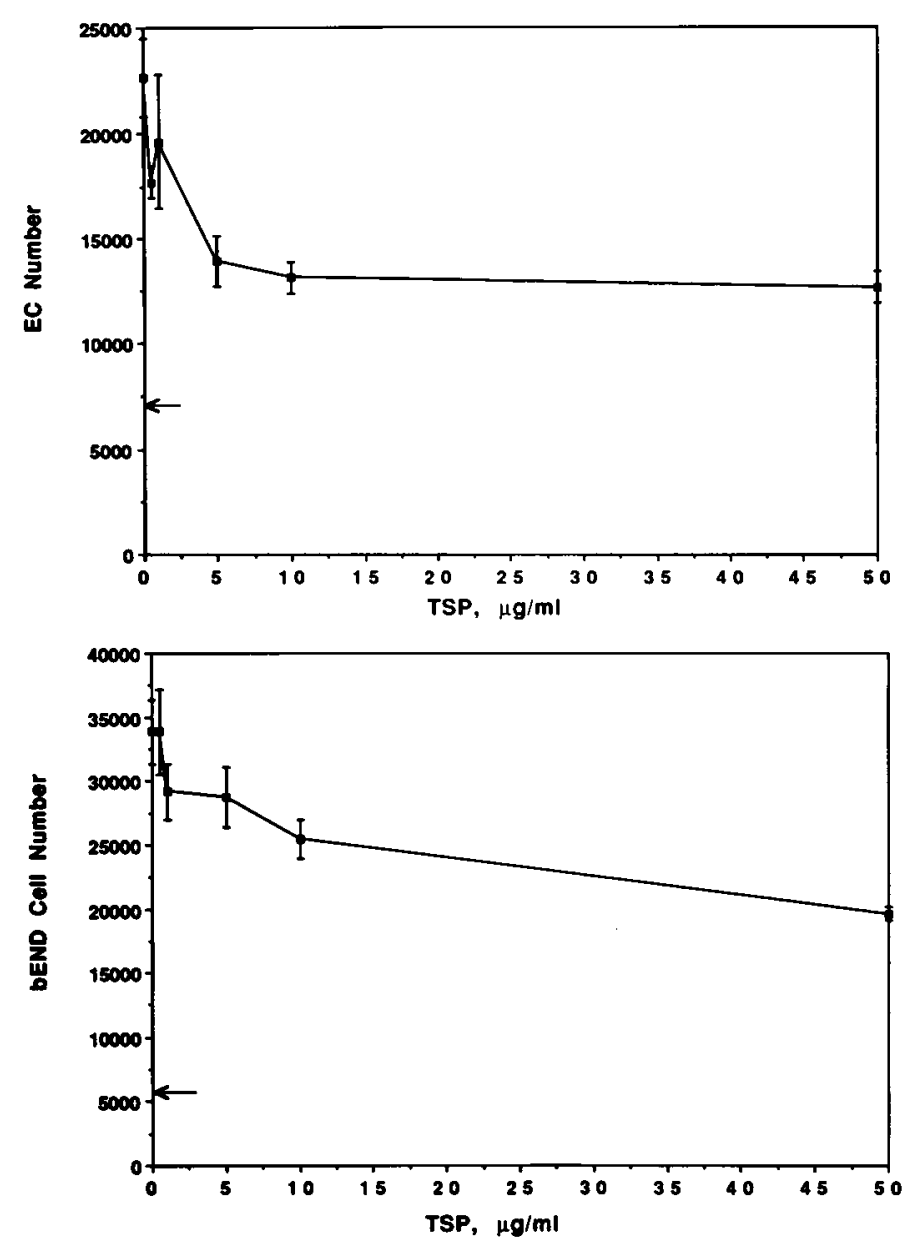

Fig. 6. Inhibition of normal and transformed EC growth by TSP. Bovine capillary EC and bEND cells were grown on 48-well dishes as described in Materials and Methods and subjected to increasing doses of TSP protein. Each data point is the mean of quadruplicate wells. Arrows represents cell number at the time of TSP addition.

al., 1991b). Thus, the absence of TSP in tumorigenic EC may contribute to the lack of normal growth control mechanisms evidenced by the formation of vascular malformations in vivo.

A recent report has described the knockout of the TGF- $\beta 1$ gene in mice by homologous recombination (Shull et al., 1992). Although these mice suffer from multifocal inflammatory disease, they exhibited no developmental abnormalities. Total disruption of several other genes thought to be developmentally important, including c-src, tenascin, and myoD, have not yielded any major developmental failures either, and explanations ranging from gene redundancy to nonfunctional protein production during embryogenesis have been offered (for a perspective see Erickson, 1993). As long as the molecular basis of development is not understood in greater detail, it suffices to say that the knockout of one member of a multigene family encoding proteins with similar functions, such as the TGF- $\beta$ s, may not yield a convincing clue to the role of that gene in development and morphogenesis.

The treatment of normal EC with TGF- $\beta 1$ leads to an increase in cell- and extracellular matrix-associated TSP-1.
This is consistent with the concept that the action of TGF- $\beta$ may be mediated, at least in part, via alterations in the extracellular matrix. In support of our hypothesis, Iruela-Arispe (1991a) reported that in cord-containing EC cultures, TSP distributes in a fibrillar array around the EC cords and suggested a role for TSP in stabilizing the vessels. Our previous observation that physical contact between EC and mural cells leads to the activation of TGF- $\beta$ has led us to postulate that the locally activated TGF- $\beta$ plays an important role in the regulation of vascular growth.

The TGF- $\beta$-stimulated deposition of TSP-1 in the microenvironment of the vessel may represent a physiological mechanism that contributes to the cessation of vessel growth. Thus, the absence of TSP in tumorigenic EC may contribute to the lack of normal growth control mechanisms evidenced by the formation of vascular malformations in vivo.

The authors are indebted to Drs Helene Sage, Werner Risau, Judah Folkman and Nathalie Dubois-Stringfellow for helpful discussions and background information, and to Ms Carlene Pavlos for preparation of the manuscript. This work was supported by NIH grant CA45548 to P.A.D.

\section{REFERENCES}

Antonelli-Orlidge, A., Saunders, K. B., Smith, S. R. and D'Amore, P. A. (1989). An activated form of TGF- $\beta$ is produced by cocultures of endothelial cells and pericytes. Proc. Nat. Acad. Sci. USA 86, 4544-4548.

Bagavandoss, P. and Wilks, J. W. (1990). Specific inhibition of endothelial cell proliferation by thrombospondin. Biochem. Biophys. Res. Commun. 170, 867-872.

Baird, A., Esch, F., Bohlen, P., Ling, N. and Gospodarowicz, D. (1985a). Isolation and partial characterization of an endothelial cell growth factor from the bovine kidney: homology with basic fibroblast growth factor. Regul. Pep. 12, 201-213.

Baird, A., Esch, F., Gospodarowicz, D. and Guillemin, R. (1985b). Retinaand eye-derived endothelial cell growth factors: partial molecular characterization and identity with acidic and basic fibroblast growth factors. Biochemistry 24, 7855-7860.

Baird, A. and Durkin, T. (1986). Inhibition of endothelial cell proliferation by type $\beta$-transforming growth factor: interactions with acidic and basic fibroblast factors. Biochem. Biophys. Res. Commun. 138, 476-482.

Chirgwin, J. M., Przbyla, A. E., MacDonald, R. J. and Rutter, W. J. (1979). Isolation of biologically active ribonucleic acid from sources enriched for ribonuclease. Biochemistry 18, 5294-3201.

D'Amore, P. A. and Smith, S. (1993). Growth factor effects on cells of the vascular wall: A survey. Growth Factors 8, 61-75.

Dubois, N. A., Kolpack, L. C., Wang, R., Azizkhan, R. G. and Bautch, V. L. (1991). Isolation and characterization of an established endothelial cell line from transgenic mouse hemangiomas. Exp. Cell Res. 196, 302-313.

Engerman, R. L., Pfaffenbach, D. and Davis, M. D. (1967). Cell turnover of capillaries. Lab. Invest. 17, 738-743.

Erickson, H. P. (1993). Gene knockouts of c-src, transforming growth factor $\beta 1$, and tenascin suggest superfluous, nonfunctional expression of proteins. $J$. Cell Biol. 120, 1079-1081.

Folkman, J., Haudenschild, C. C. and Zetter, B. R. (1979). Long-term culture of capillary endothelial cells. Proc. Nat. Acad. Sci. USA 76, 52175221.

Fort, P., Marty, L., Piechaczyk, M., EI Sabrouty, S., Dani, C., Jeanteur, P. and Blanchard, J. M. (1985). Various rat adult tissues express only one major mRNA species from the glyceraldehyde-3-phosphate-dehydrogenase multigenic family. Nucl. Acids Res. 13, 1431-1442.

Frater-Schroder, M., Muller, G., Birchmeier, W. and Bohlen, P. (1986). Transforming growth factor-beta inhibits endothelial cell proliferation. Biochem. Biophys. Res. Commun. 137, 295-302.

Funk, S. E. and Sage, E. H. (1991). Modulation of cell cycle progression in 
bovine aortic endothelial cells by a secreted protein, acidic and rich in cysteine (SPARC). Proc. Nat. Acad. Sci. USA 88, 2648-2652.

Good, D. J., Polverini, P. J., Rastinejad, F., Le Beau, M. M., Lemons, R. S., Frazier, W. A. and Bouck, N. P. (1990). A tumor suppressor dependent inhibitor of angiogenesis is immunologically and functionally indistinguishable from a fragment of thrombospondin. Proc. Nat. Acad. Sci. USA 87, 6624-6628.

Heimark, R. L., Twardzik, D. R. and Schwartz, S. M. (1986). Inhibition of endothelial cell regeneration by type-beta transforming growth factor from platelets. Science 233, 1078-1080.

Hennessy, S. W., Frazier, B. A., Kim, D. D., Deckwerth, T. L., Baumgartel, D. M., Rotwein, P. and Frazier, W. A. (1989). Complete thrombospondin mRNA sequence includes potential regulatory sites in the $3^{\prime}$ untranslated region. J. Cell Biol. 108, 729-736.

Hobson, B. and Denekamp, J. (1984). Endothelial proliferation in tumours and normal tissues: Continuous labelling studies. Br. J. Cancer 49, 405413.

Iruela-Arispe, M. L., Bornstein, P. and Sage, H. (1991a). Thrombospondin exerts an antiangiogenic effect on cord formation by endothelial cells in vitro. Proc. Nat. Acad. Sci. USA 88, 5026-5030.

Iruela-Arispe, M. L., Hasselaar, P. and Sage, H. (1991b). Differential expression of extracellular proteins is correlated with angiogenesis in vitro. Lab. Invest. 64, 174-186.

Jennings, J. C., Mohan, S., Linkhart, T. A., Widstrom, R. and Baylink, D. J. (1988). Comparison of the biological actions of TGF beta-1 and TGF beta2: differential activity in endothelial cells. J. Cell. Physiol. 137, 167-172.

Kobayashi, S. and Yamamoto, T. (1991). The molecular biologic study of the expression of thrombospondin in vascular smooth muscle cells and mesangial cells. J. Diabet. Complications 5, 121-123.

Majack, R. A., Majesky, M. W. and Goodman, L. V. (1990). Role of PDGF$\mathrm{A}$ in the control of vascular smooth muscle cell growth by transforming growth factor- $\beta$. J. Cell Biol. 111, 239-247.

Merwin, J. R., Anderson, J. M., Kocher, O., Van Itallie, C. M. and Madri, J. A. (1990). Transforming growth factor beta 1 modulates extracellular matrix organization and cell-cell junctional complex formation during in vivo angiogenesis. J. Cell. Physiol. 142, 117-128.

Montesano, R. and Orci, L. (1985). Tumor-promoting phorbol esters induce angiogenesis in vitro. Cell 42, 469-477.

Montesano, R., Vassali, J. D., Baird, A., Guillemin, R. and Orci, L. (1986). Basic fibroblast growth factor induces angiogenesis in vitro. Proc. Nat. Acad. Sci. USA 83, 7297-7301.

Montesano, R., Pepper, M. S., Mohle-Steinlein, U., Risau, W., Wagner, E. F. and Orci, L. (1990). Increased proteolytic activity is responsible for the aberrant morphogenic behavior of endothelial cells expressing the middle $\mathrm{T}$ oncogene. Cell 62, 435-445.
Muller, G., Behrens, J., Nussbaumer, U., Bohlen, P. and Birchmeier, W. (1987). Inhibitory action of transforming growth factor-beta on endothelial cells. Proc. Nat. Acad. Sci. USA 84, 5600-5604.

Penttinen, R. P., Kobayashi, S. and Bornstein, P. (1988). Transforming growth factor- $\beta$ increases mRNA for matrix proteins both in the presence and in the absence of changes in mRNA stability. Proc. Nat. Acad. Sci. USA 85, 1105-1108.

Prater, C. A., Plotkin, J., Jaye, D. and Frazier, W. A. (1991). The properdinlike type I repeats of human thrombospondin contain a cell attachment site. $J$. Cell Biol. 112, 1031-1040.

Rhodin, J. (1968). Ultrastructure of mammalian venous capillaries, venules, and small collecting veins. J. Ultrastruc. Res. 25, 425-500.

Sage, E. H. and Bornstein, P. (1991). Extracellular proteins that modulate cell-matrix interactions: SPARC, tenascin, and thrombospondin. J. Biol. Chem. 266, 14831-14834.

Sage, E. H. (1992). Secretion of SPARC by endothelial cells transformed by polyoma middle $\mathrm{T}$ oncogene inhibits the growth of normal endothelial cells in vitro. Biochem. Cell Biol. 70, 579-592.

Sato, Y. and Rifkin, D. B. (1989). Inhibition of endothelial cell movement by pericytes and smooth muscle cells: activation of a latent transforming growth factor-beta 1-like molecule by plasmin during co-culture. J. Cell Biol. 109, 309-315.

Shull, M. M., Ormsby, I., Kier, A. B., Pawlowski, S., Diebold, R. J., Yin, M., Allen, R., Sidman, C., Proetzel, G., Calvin, D., Annunziata, N. and Doetschman, T. (1992). Targeted disruption of the mouse transforming growth factor- $\beta 1$ gene results in multifocal inflammatory disease. Nature 359, 693-699.

Taraboletti, G., Roberts, D., Liotta, L. A. and Giavazzi, R. (1990). Platelet thrombospondin modulates endothelial cell adhesion, motility, and growth: A potential angiogenesis regulatory factor. J. Cell Biol. 111, 765-772.

Thomas, P. (1980). Hybridization of denatured RNA and small DNA fragments transferred to nitrocellulose. Proc. Nat. Acad. Sci. 77, 5201-5205.

Tolsma, S. S., Volpert, O. V., Good, D. J., Frazier, W. A., Polverini, P. J. and Bouck, N. (1993). Peptides derived from two separate domains of the matrix protein thrombospondin-1 have anti-angiogenic activity. J. Cell Biol. 122, 497-511.

Vlodavsky, I., Johnson, L. K., Greenburg, G. and Gospodarowicz, D. (1979). Vascular endothelial cells maintained in the absence of fibroblast growth factor undergo structural and functional alterations that are incompatible with their in vivo differentiated properties. J. Cell Biol. 83, 468-486.

(Received 1 June 1993 - Accepted 24 September 1993) 